\title{
Bivalves from the white chalk (Maastrichtian) of Denmark, IV: Nuculoida
}

\author{
CLAUS HEINBERG
}

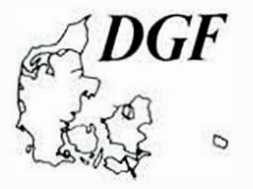

\begin{abstract}
Heinberg. C.: Bivalves from the white chalk (Maastrichtian) of Denmark, IV: Nuculoida. Bull. geol. Soc. Denmark, Vol. 37. pp. 227-236, Copenhagen, April 10th, 1989. https://doi.org/10.37570/bgsd-1988-37-18

Six species (4 of them new) of nuculoid bivalves are described. representing the gencra Nucula. Neilonella. Yoldiella and the new genus Prosilicula. The gencra Propeleda, Poroleda and Lamellileda are discussed and partly redefined on the basis of their hinges.
\end{abstract}

Claus Heinberg. Institute of Historical Geology and Palueontology. Oster Voldgade 10, DK-1350 Copen. hagen K. Denmark. November 2nd. 1988.

The present paper is number four in a series of descriptions of aragonitic bivalves from the Upper Maastrichtian of Denmark. Most of the described species are new. The previous papers dealt with the Limopsidae (Heinberg 1976), the Arcoida (Heinberg 1978) and the Cuspidariidae
(Heinberg 1979). Methodology, localities and stratigraphy may be found in Heinberg 1976.

\section{Systematic descriptions}

Six species of nuculoid bivalves are described. Two species, a Nucula and a Neilonella are rede-

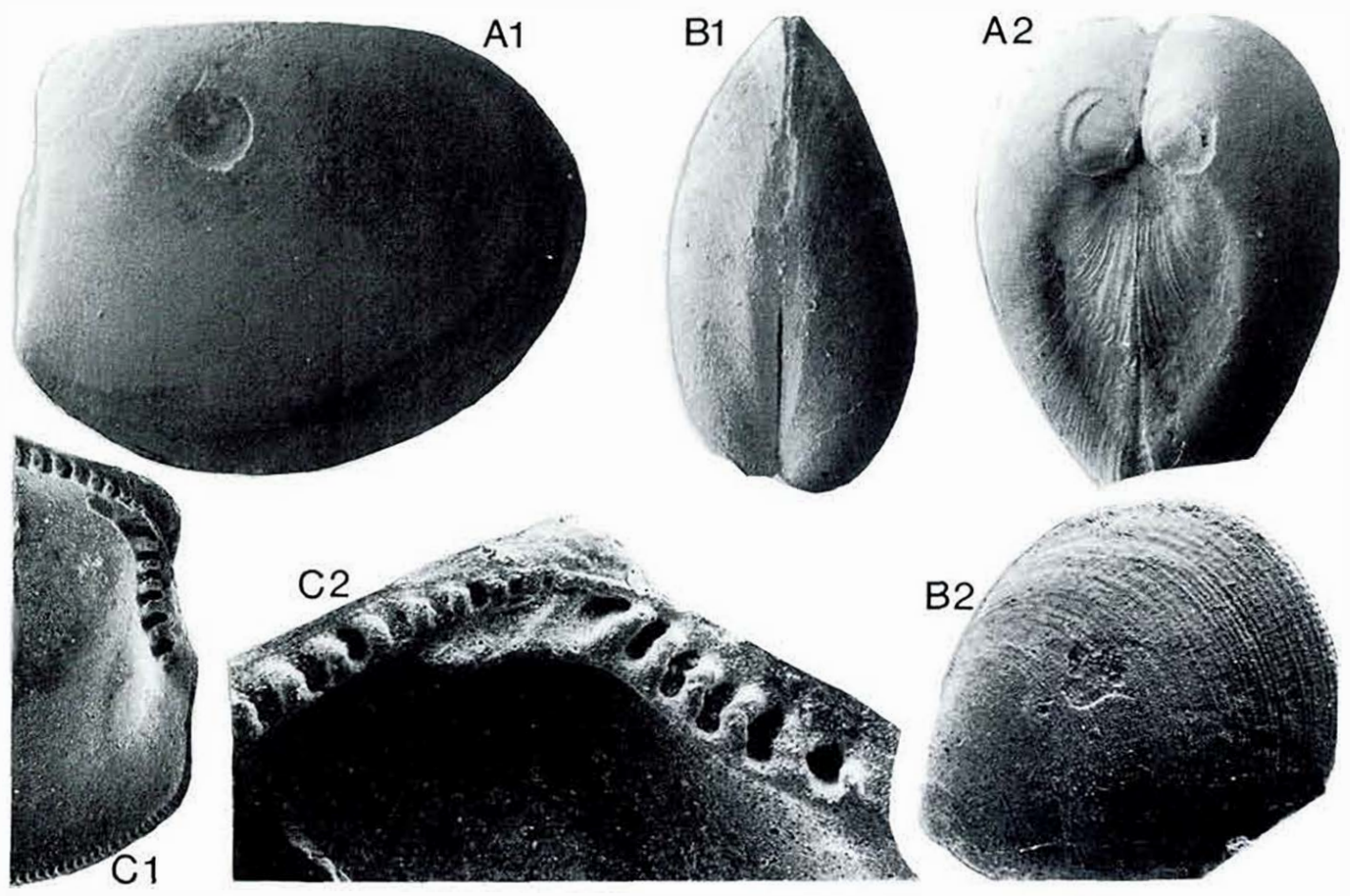

Fig. 1. Nucula (Nucula) aff. Iruncata Nilsson, 1827 A1. A2: Shell seen in lateral vicw, right valve $(\times 9)$, and in posterior vicw showing both valves $(\times 7.5)$. Silicon rubber cast. MGUH 18935. B1, B2: Dorsal $(\times 9.5)$ and lateral $(\times 8)$ vicws of MGUH 18936. Silican rubber cast. C1. C2: Inner surface of posterior part of right valve $(\times 13)$, and detail of hinge showing chondrophore $(\times 31.5)$. Silicon rubber cast. MGUH 18937. 

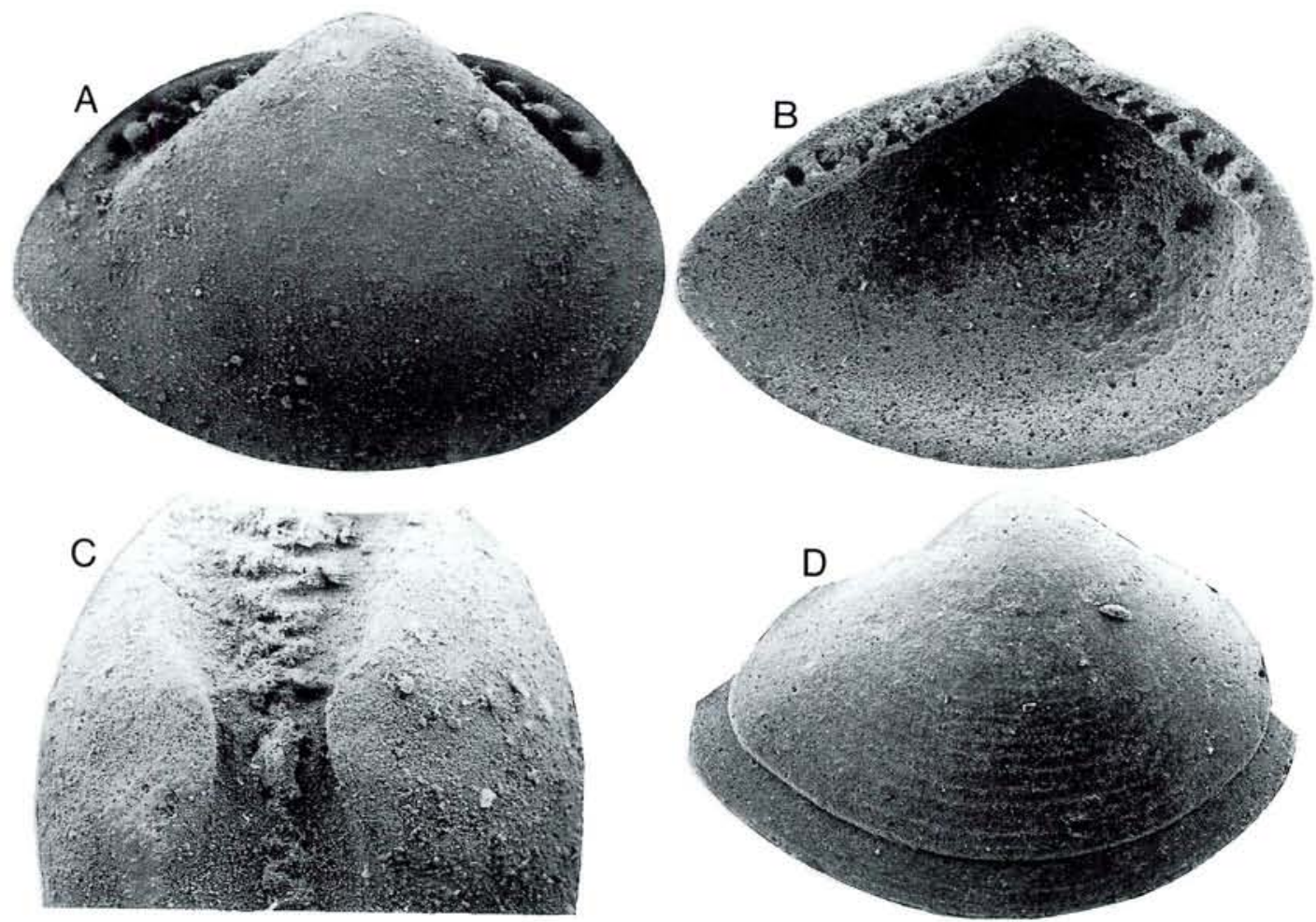

Fig. 2. Yoldiella dortea n. sp. A: Right valve in lateral view $(\times 29)$. Steinkern, MGUH 18938. B: Inner surface of left valve $(\times 26)$. Silicon rubber cast, MGUH 18939. C: Detail of hinge viewed dorsally on steinkern $(\times 53)$. MGUH 18940. D: Outer surface of right valve $(\times 29)$. Silicon rubber cast, MGUH 18941 .

scriptions while the remaining four are new. Two species of the genus Yoldiella, a Neilonella, and a species designated genotype of the new genus Prosilicula are included.

The higher taxa are based primarily on the works of Verrill \& Bush (1897), 1898), Allen \& Sanders (1973) and Sanders \& Allen (1985) and Allen \& Hannah (1986).

Family: NUCULIDAE Gray, 1824

Genus: Nucula (Nucula) Lamarck, 1799

Nucula (Nucula) aff. truncata Nilsson, 1827 MGUH 18935

Fig.1

1827, Nucula truncata Nilsson, p. 16, Pl. 5, Fig. 6 1842, Nucula truncata Nilsson, Geinitz, p. 77, Pl. XX, Fig. 25

1897, Nucula pectinata Sowerby, Hennig p. 58, Pl. 3, Fig. 30
1898, Nucula cf. truncata Nilsson, Müller p. 53 1932, Nucula truncata Nilsson, Wolanski p. 32 1986, Nucula (Nucula) truncata Nilsson, AbdelGawad p. 128, Pl. 25, Figs. 1-2.

Description: The species is a typical Nucula (Nucula) in all respects (Schenck 1934). The shell is regular triangular-ovate in outline, with a distinct posterior truncation, caused by the escutcheon. The truncation has a characteristic median convexity, constituting the median third of the distance between the posteroventral shell corner and the umbo. The hinge is well developed, having an anterior and a posterior series of teeth, forming an angle of approximately $120^{\circ}$. The anterior series is arched, whereas the posterior is straight. The figured specimen has 26 anterior hinge teeth and 9 posterior. The two series are separated by a prominent elongate chondrophore, which projects anteriorly into the lumen of the valves, almost parallel with the anterior hinge line. The ventral shell margin is finely cren- 


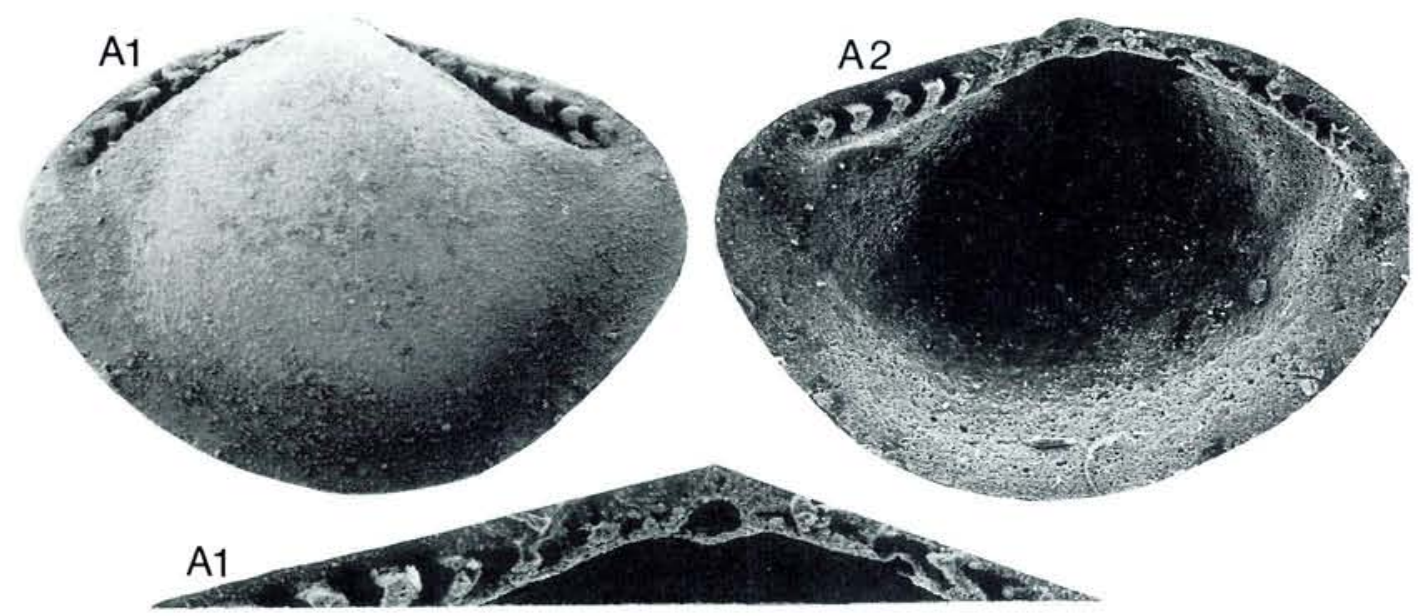

Fig. 3. Yoldiella anja n. sp. A1: Left valve in Jateral view $(\times 33)$. Steinkern. A2: Inner surface of left valve $(\times 33)$. Silicon rubber cast. A3: Detail of hinge $(\times 68)$ showing resilial pit. Left valve. Silicon rubber cast. MGUH 18942.

ulated. There are two distinct, slightly impressed, subequal adductor scars. The surface of the shell is somewhat variable with respect to the sculpture. Some specimens are smooth, while others exhibit very fine radial striations, intersected by more or less regular commarginal growth lines. There is an elongate, moderately developed area, and a distinct, heart-shaped escutcheon lacking radial striations.

Dimensions (max.): Length $11.2 \mathrm{~mm}$, height 9.2 $\mathrm{mm}$, width (two valves, steinkern) $4.8 \mathrm{~mm}$.

Discussion: The species is tentativly referred to Nucula truncata Nilsson, on the basis of the revised description by Hennig (1897). However, the holotype is an incomplete steinkern, so the matter remains unsettled. Nucula truncata Nilsson, is mentioned abundantly in the literature on Cretaceous faunas. Some examples are listed here, and further references may be found in Abdel-Gawad (1986). However, the quality of many of the illustrations, including the original, does not permit comparisons in any detail. It therefore remains an open question, whether the frequent use of the name is justified or not.

Among recent species of Nucula, specific differences in shell characters are often very subtle. Several species may therefore be disguised under the name $N$. truncata.
Material: Stevns Klint in general: 11 specimens, Kulsti: 16, Holtug: 15, Eskesti: 3 and Rødvig: 1 specimen.

Family: NUCULANIDAE Adams \& Adams, 1858

Genus: Yoldiella Verrill \& Bush, 1897

Yoldiella dortea $\mathrm{n}$. sp.

Fig. 2

Holotype MGUH 18938. Length $2.5 \mathrm{~mm}$, height $1.7 \mathrm{~mm}$, width (one valve) $0.5 \mathrm{~mm}$.

Additional material MGUH 18939 \& 18941.

Type locality: Stevns Klint.

Type stratum: The top hardground of the Upper Maastrichtian white chalk.

Diagnosis: A small egg-shaped, slightly rostrate Yoldiella, with a prominent umbo. Hinge with two well developed straight series of chevronshaped teeth, separated by a triangular resilial pit.

Description: The shell is regular subovate, eggshaped to slightly rostrate in outline. The umbo is situated somewhat anterior to the midline, resulting in an anterior:posterior ratio of 1:1.4. The shell is relatively wide. The umbo is prominent, completely obscuring the umbonal part of the hinge, viewed laterally on the steinkern. The hinge is well developed, especially for such a small animal. It consists of two straight series of chevron-shaped teeth, separated by a distinct tri- 
angular resilial pit, ventrally on the narrow hinge plate. Each series consists of approximately 10 teeth. The two series form an angle of $125^{\circ}$. Anterior and posterior adductor scars are faintly marked. The surface of the shell is smooth, with low, regular rounded, commarginal ribs. There is an extremely weak carina, directed postero-ventrally from the umbo.

Dimensions (max.): Length $2.6 \mathrm{~mm}$, height 2.7 $\mathrm{mm}$, width $1.3 \mathrm{~mm}$ (two valves, steinkern).

Discussion: The morphology of the species conforms with the original generic diagnosis of Verill \& Bush (1897). Consequently, it has a general morphology very close to that of the genotype Yoldiella lucida (Lovén). In particular the size and position of the resilial notch, and the faintly rostrated wedge-shape of the shell are regarded as diagnostic. The species differs from the somewhat similar Jupiteria, occurring e.g. in the Maastrichtian of North America (Speden 1970) in having a smaller resilial pit, a more regular ovate outline and no posterodorsal concavity.

Material: Stevns Klint in general: 5 specimens, Kulsti: 6, Holtug: 1, Eskesti: 1 specimen.

Yoldiella anja $\mathrm{n} . \mathrm{sp}$.

Fig. 3

Holotype MGUH 18942. Height $1.5 \mathrm{~mm}$, length $2.2 \mathrm{~mm}$, width (one valve, steinkern) $0.8 \mathrm{~mm}$. Type locality: Stevns Klint.

Type stratum: The top hardground of the Upper Maastrichtian white chalk.

Diagnosis: A small Yoldiella, veneroid in outline and with a moderate umbo. Hinge consisting of a straight posterior and a slightly curved anterior series of chevron-shaped teeth, separated by a minute resilial pit in the ventral margin of the hinge plate.

Description: The shell is obliquely ovate in outline, inequilateral, nearly veneroid. It has a pointed anterior end, and a posteroventral truncation, which causes a maximum in curvature posterodorsally and ventrally, anterior to the midline. The shell is broadly lenticular in shape, with a width:height ratio of 1:1 (two valves, steinkern). The hinge is divided into a straight posterior series of 9-10 chevron-shaped teeth, and an arched anterior series of 7-8 similar teeth. The two series form an angle of approximately $140^{\circ}$. A resilial notch, intersecting the ventral margin of the hinge-plate, separates the two series. Both anterior and posterior adductor scars are faintly inserted in the shell. The outer surface is smooth.

Dimensions (max.): Length $2.2 \mathrm{~mm}$, height 1.5 $\mathrm{mm}$, width (two valves, steinkern) $1.5 \mathrm{~mm}$.

Discussion: The species is considered to be a Yoldiella because of the resilium, and the general shape of the shell, reminiscent of the Recent Yoldiella abyssorum (see e.g. Knudsen 1970).

Material: Stevns Klint, Eskesti: 3 specimens, Kulsti: 1, Holtug: 1 specimen.

Family: SATURNIIDAE Allen \& Hannah, 1986. Genus: Neilonella Dall, 1881

Taxonomic remarks: According to Verrill \& Bush (1887), the genus Neilonella is characterized by an ovate swollen shell with obtuse ends, the posterior part somewhat larger than the anterior, and a concentrically grooved surface. The ligament is external, amphidetic, extending in front of and behind the umbo, with a small resilial notch in the dorsal shell margin, below the umbo. The dentition of the hinge is continuous, or interrupted by a narrow edentulous space. Dall (1886), describing the genotype Neilonella corpulenta, stated that the ligament extends equally before and behind the beaks. He further stressed the presence of a minute resilial notch above the line of dentition. Together with the section Neilonella, Dall (1886) operated with the section Saturnia. Allen \& Hannah (1986) regard Neilonella a synonym of Saturnia, and Verrill \& Bush (1898) include both in Neilonella (Saturnia being preoccupied). However, since Allen \& Hannah (1986) define Saturnia as having an opisthodetic ligament the two taxa may be equally valid. The distinct amphidetic ligament described by Dall (1881, 1886), and Verill \& Bush (1898), and found in the following species, is thus regarded as a distinctive character, separating Saturnia and Neilonella. Chavan (1946) erected the genus 


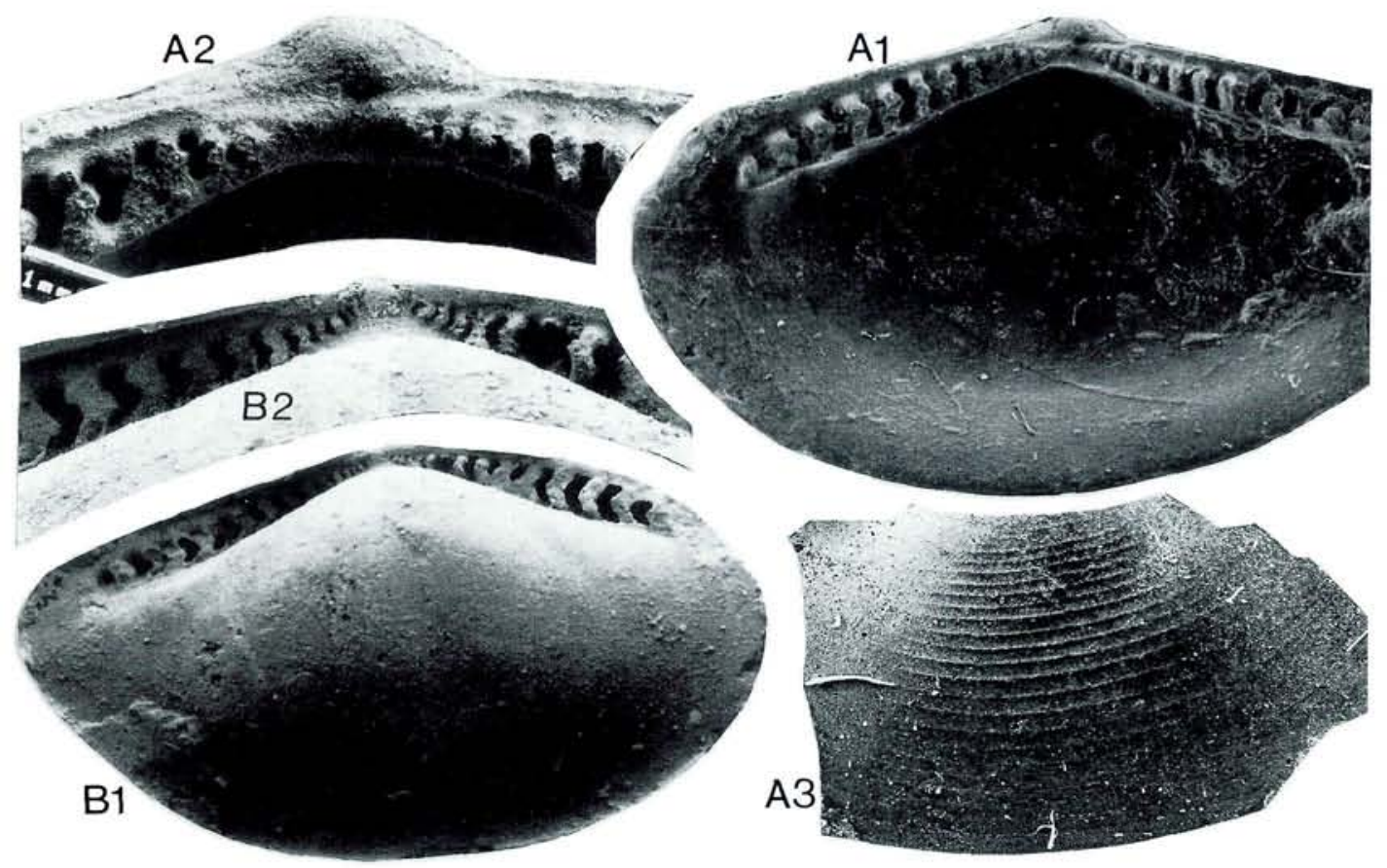

Fig. 4. Neilonella aff. försteri J. Müller. A1, A2, A3: Inner surface of right valve $(\times 10)$, detail of hinge showing resilial pit $(\times 28)$ and outer surface $(\times 15)$. Silicon rubber cast, MGUH 18943, B1, B2: Right valve in lateral view $(\times 10.5)$ and detail of hinge $(\times 26)$. Steinkern, MGUH 18944.

Mesosacella with Nucula foersteri (OD) as genotype. Subsequently Van de Poel (1956), describing Phaenodesma (Mesosacella) försteri (Müller, 1847), has revised Chavan's diagnosis of Mesosacella. Van de Poel claims that the ligament of Mesosacella försteri (sensu Chavan), and thus of Mesosacella, is amphidetic. This is directly opposed to the original definition by Chavan (1946) stating that the ligament of Mesosacella is positioned "derière le crochet" (p. 197). Provided that Van de Poel and Chavan are talking about the same, which they probably are, Mesosacella must be regarded superflous revised or not, and should be replaced by Neilonella, a genus which according also to Van de Poel "undoubtedly" is close to Mesosacella. The amphidetic ligament, and the small central resilial pit, are among the diagnostic characters supporting this revision. Species with comparable morphology, but opisthodetic ligament, may be referred to the genus Saturnia (sensu Allen \& Hannah, 1986).

The genus Malletia, with which Neilonella may be confused, is restricted to forms that are smooth, compressed, oblong or elliptical and having a blunt posterior part. This is in agree- ment with Sanders \& Allen (1985), who defined Malletia as follows: thin, transluscent, inequilateral, slender or swollen shells with exterior ligament, where the posterior part is the longest, a small resilium inserted in the hinge plate and an edentulous space separating the tooth series of the hinge. Sanders \& Allen (1985, p. 196) mentioned an alternative group with thick, more or less equilateral shells and strong concentric ornament. This group includes Neilonella Dall, 1881, which they did not include in the Malletiidae. Following Allen \& Hannah (1986), Neilonella is included in the family Saturniidae.

Neilonella aff. försteri (J. Müller, 1847)

Fig. 4

MGUH 18943 \& 18944

1847, Nucula Försteri, J. Müller, p. 16, Pl. 2, Fig. 1

1889, Leda Försteri Müll., Holzapfel, p. 202, Pl. XXI, Fig. 13-16.

1898, Leda Försteri J. Müll. sp., G. Müller, p. 54, Fig. 14 

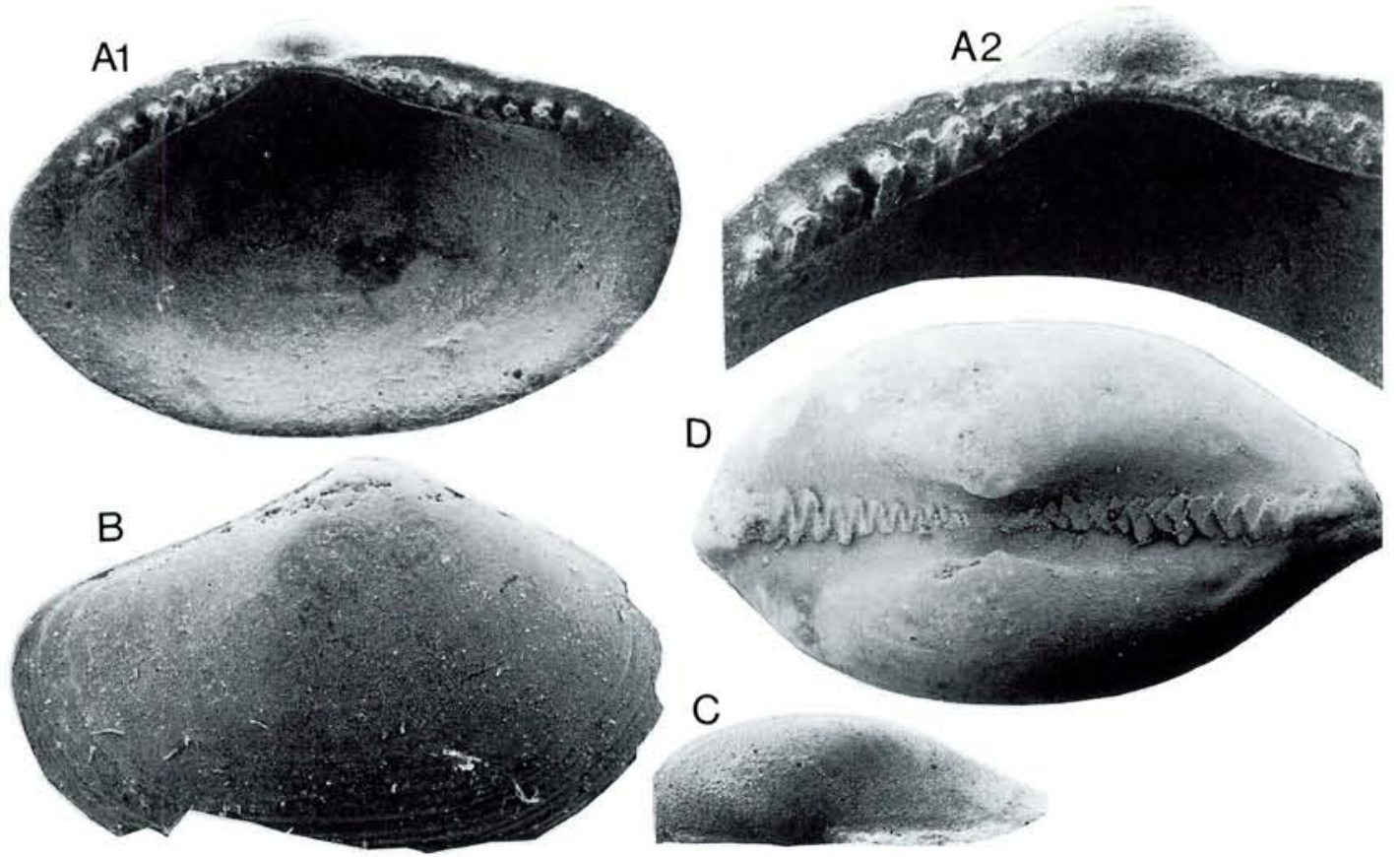

Fig. 5. Neilonella susannae $\mathrm{n}$. sp. A1, A2: Inner surface $(\times 13)$ and detail of hinge $(\times 22)$ of a right valve. Silicon rubber cast, MGUH 18945. B: Outer surface of right valve in lateral view $(\times 12)$. Silicon rubber cast, MGUH 18946. C: Outer surface of right valve in dorsal view $(\times 7.5)$. Silicon rubber cast, MGUH 18947. D: Steinkern in dorsal view (× 13). MGUH 18948.

1943, Leda försteri Müller, Van der Weijden, p. 30, Taf. 1, Figs. 4-5, Taf. 9, Figs. 21-22.

1947, Mesosacella försteri (Müller), Chavan, p. 197.

1956, Phaenodesmia (Mesosacella) försteri (Müller, 1847), Van de Poel, p. 3, Pl. I, Fig. 3a,b.

1986, Nuculana (Nuculana) foersteri (J. Müller, 1847), Abdel-Gawad, p. 131, Pl. 25, Figs. 16-17.

Description: Shell regular elongate-ovate in outline, almost equilateral with a posterior:anterior ratio of $1: 1$. Anterior part of shell regularly rounded, while posterior part has a slightly concave dorsal margin, and a fairly sharp posterodorsal shell angle. The shell is flat, laterally compressed, with a smooth concavity on the steinkern around the point of maximum shell width. The width (two valves) is approximately $60 \%$ of the height, measured on the steinkern. The umbo is small and low, permitting the entire hinge to be seen on the steinkern in lateral view. The hinge is well developed, consisting of two series of 13-15 chevron-shaped teeth, separated by a very nar- row edentulous space below umbo. The two series form an angle of $145^{\circ}$. The ligament is elongate, external, with a small resilium situated in a minute notch in the shell margin below umbo. The external ligament extends equally on either side of the notch. It is situated in a shallow groove along the dorsal shell margin. The surface of the shell is smooth, with regular commarginal striae. These striae are narrow bands inclined towards the umbo, giving the surface the appearance of very flat steps, wide and extremely low. The striation disappears on the posterodorsal slope of the shell, which is smooth.

Dimensions (max.): Length $7.7 \mathrm{~mm}$, height 4.3 $\mathrm{mm}$, width (two valves, steinkern) $2.5 \mathrm{~mm}$.

Discussion: The compressed shell could indicate that the species is a Malletia (sensu Sanders \& Allen 1985), but in all remaining characters it appears to be a Neilonella. In particular the ligament seems to be identical to that of the genotype, and typically malletiid, while the ligament of Malletia proper has a longer postero-umbonal part than antero-umbonal part. The very narrow 

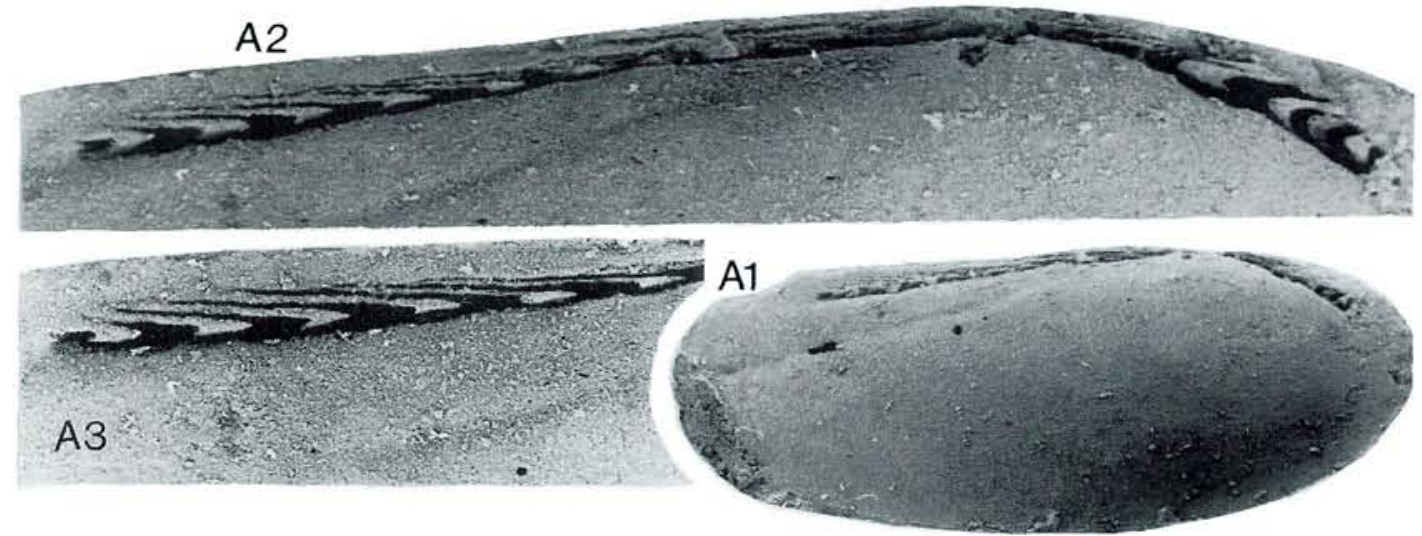

Fig. 6. Prosilicula parallelodonta $n$. gen. et sp. A: Lateral view of right valve $(\times 10.5)$. A2: Hinge $(\times 25.5)$, A3: posterior part of hinge (× 29). Steinkern, MGUH 18949.

edentulous space, the equilateral ovate shell and the ornamentation also distinguish the species from Malletia.

Material: 2 specimens from Kulsti, Stevns Klint.

\section{Neilonella susannae n. sp.}

Fig. 5

Holotype: MGUH 18945. Height $3.0 \mathrm{~mm}$, length $5.1 \mathrm{~mm}$, width (one valve, steinkern) $1.0 \mathrm{~mm}$. Type locality: Stevns Klint.

Type stratum: The top hardground of the Upper Maastrichtian white chalk.

Diagnosis: A moderate sized sub-rectangular Neilonella, inequilateral with prominent umbo. Hinge a continous curved series of chevronshaped teeth which diminishes below umbo.

Description: The shell is rounded, sub-rectangular in outline, slightly inequilateral with an anterior:posterior ratio of approximately $1: 1.3$. The anterior part is rounded, while the posterior is somewhat truncated with a slightly projecting dorsal shell corner. The shell is broad, inflated, the width (two valves, steinkern) constituting ca. $85 \%$ of the height. The hinge is a continuous wide arch of chevron-shaped teeth which diminishes in size towards umbo, very much like that of Neilonella sp. in Soot-Ryen 1966. The two series of teeth form an angle of approximately $124^{\circ}$. The anterior adductor scar is well marked, while the posterior is obsolete. The ligament appears to have been external, though no trace has been observed. However, the continuous hinge leaves no space for an internal ligament. Indication of a resilial notch below umbo has been observed in one case, but the material is inconclusive. The umbo is prominent, inflated, completely obscuring the umbonal part of the hinge, viewed laterally on the steinkern. The shell is thick, the surface smooth with irregularly spaced growth lines. A narrow escutcheon is demarcated by an indistinct ridge, and an elongate lunula is also present.

Dimensions (max.): Length $6.1 \mathrm{~mm}$, height 3.5 $\mathrm{mm}$, width (two valves, steinkern) $3.0 \mathrm{~mm}$.

Discussion: The species is regarded as a Neilonella (sencu Verill \& Bush 1898), basically because of the continuous dentition, the ovate inflated shell, the prominent umbo, the considerable width of the shell and thickness of the valves.

Material: Stevns Klint in general: 1 specimen, Holtug: 8, Kulsti: 8, Eskesti: 2 and Rødvig: 1 specimen.

Family: SILICULIDAE Allen \& Sanders, 1973 Genus: Prosilicula n. gen.

Type: Prosilicula parallellodonta $\mathrm{n}$. gen et. $\mathrm{n}$. sp. Fig. 6

Note: The species is so characteristic, that the designation of a new genus is thought to be justified, despite the fact that only one specimen has been found. 
Diagnosis: Nuculanoid protobranch having elongate, compressed shell, resilium internal, opisthodetic, posterior part of the hinge long, teeth modified chevron-shaped with extremely elongated dorsal arms forming lamellae parallel to the dorsal shell margin. Each lamella-shaped tooth overlaps the more lateral teeth dorsally. Anterior part of the hinge has chevron-shaped teeth, with somewhat elongated dorsal arms that overlap dorsally.

Discussion: The genus is distinguished from $\mathrm{Po}$ roleda Tate (sensu Newell 1969) and Propeleda Iredale (sensu Allen \& Hannah 1986) and Lamellileda (sensu Allen \& Hannah 1986 = Propeleda of Newell 1969) on the dentition. Poroleda has almost normal chevron-shaped teeth in the anterior series, while the posterior series consists of short, completely lamellate teeth which are not parallel to the hinge margin, and hardly overlapping (see eg. Hedley, 1906). Propeleda has normal chevron-shaped teeth, except for the more proximal ones, which may have the shape of small lamellae owing to reduction or omission of the ventral arm of the chevron. Lamellileda (Cotton 1930, p. 227) has exclusively lamellate teeth with no chevrons. The same is the case in Silicula. In all genera, the lamellate teeth overlap the lateral teeth dorsally, a unifying character in the family Siliculidae (Allen \& Sanders 1973).

\section{Prosilicula parallellodonta $\mathrm{n}$. sp.}

Fig. 6

Holotype: MGUH 18949. Length $7 \mathrm{~mm}$, height $2.6 \mathrm{~mm}$, width (one valve, steinkern) $0.7 \mathrm{~mm}$.

Type locality: Stevns Klint, immediately north of Holtug chalk pit.

Type stratum: The top hardground of the Upper Maastrichtian white chalk.

A moderate sized Prosilicula, elongate ovate, strongly inequilateral with a minute umbo. Ligament internal. Hinge divided into a short curved anterior series of chevron-shaped teeth with moderately elongated dorsal arms, and a long straight posterior series with heavily elongated dorsal arms.

Description: Shell elongate ovate, compressed, strongly inequilateral having an anterior:posterior ratio of 1:2.2. Dorsal margin straight, sub- parallel to the gently curved ventral margin. Anterior and posterior ends rounded. Umbo small and low, not obscuring the hinge, viewed laterally on the steinkern. The hinge is long, divided into a long posterior and a short anterior series of teeth by an opisthodetic resilium. The two series form an angle of approximately $150^{\circ}$. The posterior series consists of 9-10 chevron-shaped teeth, with extremely elongated dorsal arms, and somewhat reduced ventral arms. The traditional protobranch chevron tooth has been modified into lamellae, with a small hook. Each lamellate tooth is parallel with the dorsal shell margin, and each lamella overlaps the more lateral teeth dorsally. The anterior series consists of 5-6 chevronshaped teeth, with elongated dorsal arms. The lamellate dorsal arm of each chevron forms an angle with the shell margin and overlaps the more lateral teeth dorsally. No adductor scars are visible. A shallow internal ridge extends from the umbo to a position close to the middle of the posterior shell margin, identical to the ridge in Propeleda, figured by Allen \& Hannah 1986. The outer surface of the shell is unknown.

Dimensions $(\max$.$) : Those of the holotype.$

Discussion: A number of extremely elongate Recent nuculanoid species from the Australian region constitute a series of hinge types that may illustrate successive morphological stages in the possible evolution from a typical nuculanoid hinge with chevron shaped teeth, to a siliculoid hinge of exclusively lamellate teeth. Among these species are:

Poroleda lanceolata Hutton, in. Hedley 1906, Pl. II, fig. 7.

Poroleda huttoni (Teninson Woods), in. Ludbrook 1901, Pl. 3, fig. 10.

Poroleda spathulata Hedley 1914. Pl. 1xxviii, fig. 17, 18.

Propeleda ensicula (Angas), in Newell 1969, Fig. A6, 9a,b.

Lamellileda typica Cotton 1930, Fig. 4, and

Lamellileda tatei (Hedley), in. Ludbrook 1961, Pl. 3, Fig. 7.

There is a great deal of confusion concerning the generic status of these species. The figures in Cotton (1930) of Lamellileda typica and in Newell (1969) of Propeleda ensicula are the same. Their concepts of the two genera are also identi- 


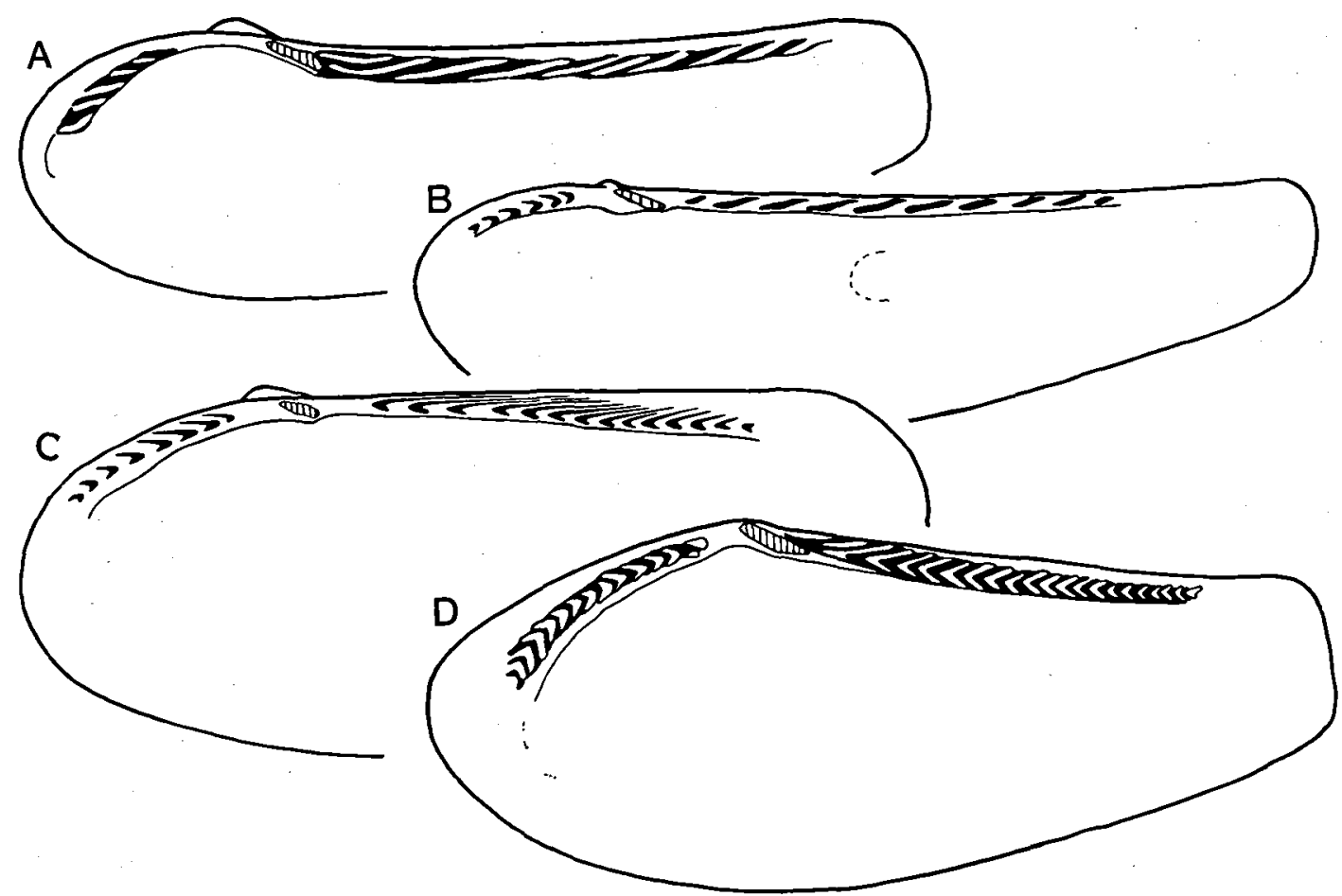

Fig. 7. Species typifying four genera of elongate protobranchs with lamellate teeth. A: Lamellileda Cotton, 1930, B: Poroleda Hutton, 1893, C: Prosilicula Heinberg, 1989, D: Propeleda Iredale, 1924. The figures are redrawn from: Cotton 1930, Hedley 1906. Heinberg 1989 and Ludbrook 1961.

cal: all hinge teeth are lamellate. Allen \& Hannah (1986) figured a Lamellileda with modified chevron shaped teeth in the anterior tooth-series. This is traditionally regarded a Poroleda-type of hinge. (eg. Hedley 1906), a genus emended by Allen \& Hannah (1986) and included partly in Jupiteria, partly in Propeleda. However, it is here suggested that on basis of the characteristic dentition, the genus Poroled $a$ be reinstated for species with exclusively lamellate teeth in the posterior series, and chevron-shaped teeth in the anterior, including such species as Poroleda spathulata $\mathrm{He}$ dley and Poroleda lanceolata sensu Hedley (1914) and Newell (1969).

The hinge of Lamellileda is defined by having exclusively lamellate teeth in both the posterior and the anterior series (Cotton 1930). Consequently, Propeleda ensicula in Newell (1969) is a Lamellileda.

Propeleda (Iredale 1924) is defined by Allen \& Hannah as having lamellar proximal teeth with reduced or absent ventral arms of the otherwise normal chevron-shaped teeth. This diagnosis fits well with the hinge of Poroleda huttoni (sensu
Ludbrook 1961) which may then be a good representative of the Propeleda-hinge (Fig. 7D). Allen \& Hannah (1986) include Propeleda in the family Nuculanidae. Within this range of morphologies, Prosilicula is a possible precursor to the Siliculidae Allen \& Sanders, 1973 (Sanders pers. comm.), including the Recent genera Silicula Jeffreys and Lamellileda Cotton (Allen \& Hannah 1986). The most distinctive shell character unifying the three genera, appears to be the dorsally overlapping lamellate teeth. This is opposed to the Lametilidae Allen \& Sanders, where the lamellate teeth overlap the more lateral teeth ventrally, indicating reduction of the dorsal arm of the chevron.

Morphologically, the four genera thus constitute a cline (Fig. 7). In Prosilicula all teeth have chevrons. The dorsal arms in the posterior series are heavily extended, forming lamellae, while this tendency is less pronounced in the anterior series. In Poroleda only the anterior series of teeth are chevron-shaped, while the posterior series consist of lamellate teeth exclusively, and in both Lamellileda and Silicula all teeth are com- 
pletely lamellate (or nearly so). In Lamellileda only the posterior series of lamellate teeth are parallel with the dorsal shell margin, while in Silicula that stage has been reached in both series.

The fourth genus Propeleda, may then represent the morphology of a possible ancient nuculanoid ancester, with only slight reduction of the ventral arms of the chevrons.

\section{Acknowledgements}

This study has been supported by grants from the Carlsberg Foundation. I thank Dr. J. Knudsen for constructive criticism of the manuscript, and Dr. H. L. Sanders for discussion on Prosilicula. Dr. R. G. Bromley read the manuscript and improved the language of the manuscript.

\section{Dansk sammendrag}

Som en fortsættelse af den systematiske beskrivelse af aragonitskallede muslinger fra det hardnede skrivekridt fra Stevns Klint (Heinberg 1976, 1978, 1979), er 6 arter af protobranche muslinger (familierne Nuculidae og Nuculanidae) beskrevet. 4 af arterne er nye, mens de 2 er genbeskrivelser. Arterne fordeler sig på følgende slægter: Nucula en art, Neilonella to arter, Yoldiella to arter, og en art som har givet anledning til oprettelsen af en ny slægt: Prosilicula Heinberg. En række recente slægter med lamelformede tænder diskuteres og revideres.

\section{References}

Abdel-Gawad, G. I. 1986: Maastrichtian non-cephalopod molluscs (Scaphopoda, Gastropoda and Bivalvia) of the Vistula Valley, Central Poland. Acta Geol. Pol. 36 (1-3), 69-224.

Allen, J. A. \& Hannah, F. J. 1986: A reclassification of recent genera of the subclass Protobranchia (Mollusca: Bivalvia). J. Conch. 32, 225-249.

Allen, J. A. \& Sanders, H. L. 1973: Studies of deep-sea Protobranchia: The families Siliculidae and Lametilidae. Bull. Mus. Comp. Zool. Harvard 145, 263-310.

Chavan, A. 1946: L'Evolution des faunes marines de Mollusques dans le Nord-Quest de l'Europe, de la fin du Crétacé a celle de l'éocéne. Bull. Soc. Géol. Fr. (5), XVI, 193-212.

Cotton, B. C. 1930: Pelecypoda of the "Flindersian" region, Southern Australia. Rec. S. Austr. Mus. 4 (2), 223-240.

Dall, W. H. 1886: Report on the Mollusca, Part I. Brachiopoda and Pelecypoda. Bull. Harvard Univ., Museum Comp. Zoology, 12 (6), 171-318.

Geinitz, H. B. 1842: Charakteristik der Schichten und Petrefakten des sachsisch-böhmischen Kreidegebirges, III, 63-116.

Hedley, C. 1906: Results of dredging on the continental shelf of New Zealand. New Zealand Inst. Trans., 38, 68-76.

- 1914: Studies on Australian Mollusca, Part 12: Linnean Soc. New South Wales, Proc., 39, 695-755.

Heinberg, C. 1976: Bivalves from the white chalk (Maastrichtian) of Denmark: Limopsidae. Bull. geol. Soc., Denmark 25, 57-70.

- 1978: Bivalves from the white chalk (Maastrichtian) of Denmark, II: Arcoida. Bull. geol. Soc., Denmark 27, 105-116.

- 1979: Bivalves from the white chalk (Maastrichtian) of Denmark, III: Cuspidariidae. Bull. geol. Soc., Denmark $28,39-45$.

Hennig, A. 1897: Revision af Lamellibranchiaterna i Nilssons "Petrificata Suecana formationis cretaceae". Kungl. Fysiogr. Sällskapets $i$ Lund Handlinger. Ny Följd. 8, 1-66.

Holzapfel, E. 1889: Die Mollusken der Aachener Kreide. II. Lamellibranchiata. Palaeontographica, 35, 139-168.

Knudsen, J. 1970: The Systematics and biology of abyssal and hadal Bivalvia. Galathea Rep. 11, 241 pp.

Ludbrook, N. H. 1961: Revision of the Tate molluscan types: Pelecypoda - Nuculidae and Nuculanidae. Trans. Roy. Soc. S. Aust. 85, 55-65.

Newell, N. D. 1969 in Moore (ed.) Mollusca Treatise on Invertebrate Paleontology, N (1): 489 pp. Lawrence: Kansas Univ. Press.

Müller, G. 1898: Die Molluskenfauna des Untersenon von Braunschweig und Ilsede; I, Lamellibranchiaten und Glossophoren. Abh. Preuss. Geol. Landesanst., N. F., 25, 1-140.

Nilsson, S. 1827: Petrificata Suecana formationis cretaceae. 37 pp.

Poel, L. Van de, 1956: Fauna malacologique du Hervien. Bull. Inst, roy. Sci, nat. Belgique, XXXII, no. 19, 1-23.

Sanders, H. L. \& Allen, J. A. 1985: Studies on deep-sea Protobranchia (Bivalvia); the family Malletiidae. Bull. Br. Mus. nat. Hist. (Zool.), 49 (2), 195-238.

Schenck, H. G. 1934: Classification of nuculoid pelecypods. Bull. Mus. roy. d'Hist. nat. Belg., X (20), 1-78.

Soot-Ryen, T. 1966: Revision of the pelecypods from the Michael Sars North Atlantic Deep-Sea Expedition 1910. With notes on the family Verticordiidae and other interesting species. Sarsia 24 (1), 1-31.

Speden, I. G. 1970: The type Fox Hills formation, Cretaceous (Maastrichtian), South Dakota, Part 2. Systematics of the Bivalvia. Bull. Peabody Mus., 33, 222 pp.

Weijden, W. J. M. Van der, 1943: Die macrofauna der hervenschen Kreide mit besonderer Berücksichtigung der Lamellibranchiaten. Mededel. geol. Sticht, C-IV-2-No. 1, 1-139.

Verrill, A. E. \& Bush, K. J. 1987: Revision of the genera of Ledidae and Nuculidae of the Atlantic coast of the United States. Am. Journ. Sci., ser. 4, v. 3 (153), 51-63.

- 1898: Revision of the deep-water Mollusca of the Atlantic coast of North America with descriptions of new genera and species. U.S. Natl. Museum, Proc., 20, 775-901. 